\title{
SIMBOL PADA REKABENTUK MASJID MUHAMMADI, KOTA BHARU, KELANTAN: SATU PENELITIAN AWAL
}

\author{
NUR NAJWA HANIM SAIDI \\ NORAZLINDA MOHAMED ROSDI \\ DAENG HALIZA DAENG JAMAL \\ nurnajwa937@yahoo.com*, norazlinda@umk.edu.my**, haliza.j@umk.edu.my**
}

\begin{abstract}
Abstrak
Simbol memainkan peranan penting dalam melihat keindahan nilai estetika sesuatu rekabentuk bangunan masjid. Ini kerana keunikan rekabentuk sesebuah masjid warisan banyak dipengaruhi oleh rekabentuk simbol yang dipilih yang mempunyai falsafah tertentu. Pemilihan simbol yang tepat menjadikan rekabentuk masjid lebih menarik dan cantik. Kajian ini bertujuan merungkai pemilihan simbol bagi setiap rekabentuk pada bangunan Masjid Muhammadi, Kota Bharu Kelantan. Simbol yang diambilkira dalam kajian ini adalah termasuk ragam hias, motif (flora dan fauna), geometri dan kaligrafi. Kaedah penyelidikan yang digunakan untuk mendapatkan maklumat ialah melalui kaedah pemerhatian. Kaedah pemerhatian ini digunakan bagi melihat ragam hias dalam rekabentuk Masjid Muhammadi. Hasil kajian menunjukkan simbol yang digunakan dalam ragam hias masjid warisan ini lebih menekankan kepada motif yang berunsurkan alam flora, kaligrafi dan corak.
\end{abstract}

Kata Kunci: Masjid, Ragam Hias, Rekabentuk, Simbol, Warisan 


\title{
SYMBOL IN THE DESIGN OF MASJID MUHAMMADI, KOTA BHARU, KELANTAN: A PRELIMINARY INVESTIGATION
}

\author{
NUR NAJWA HANIM SAIDI \\ NORAZLINDA MOHAMED ROSDI \\ DAENG HALIZA DAENG JAMAL \\ nurnajwa937@yahoo.com*, norazlinda@umk.edu.my**, haliza.j@umk.edu.my***
}

\begin{abstract}
Symbol has an important role in appreciating the aesthetic value of a heritage mosque. The uniqueness of a heritage mosque is influenced by the selected symbols which have their own philosophy. A right selection can make the design of the mosque more attractive and more beautiful. This study aims to unravel the selection of symbols in the design of Masjid Muhammadi, Kota Bharu Kelantan. These symbols include decoration, motifs (flora and fauna), geometry and calligraphy. The research method used to obtain information is qualitative through observation. It is observed that the symbols used in the decoration of this heritage mosque are more of a motif based on the nature of flora, calligraphy and patterns.
\end{abstract}

Keyword: Decorate, Design, Heritage, Mosque, Symbol 


\subsection{Pengenalan}

Menurut Mohd Ismail \& Kamarul Azmi (2008), masjid berasal daripada perkataan sajada yang bermaksud tempat sujud. Sujud (sujudun) adalah meletakkan kening ke tanah. Sujud mengandungi maksud menyembah selain kepada Tuhan. Sujud mengandungi makna hormat kepada sesuatu yang dipandang besar atau agung manakala sejadah berasal daripada kata sajjadatun yang menjadi tempat digunakan untuk sujud dan kemudian menjadi selembar karpet atau sajadah yang dibuat khusus untuk menjadi alas menunaikan solat. Masjid dalam erti lain adalah tempat yang digunakan untuk sujud bagi umat Islam dalam menunaikan ibadatnya yang dituntut oleh Tuhan.

Menurut Asmak Ali dan Hashim Mat Said (2008), masjid merupakan sebuah institusi yang berperanan sebagai paksi masyarakat dalam seharian kehidupan manusia yang bergelar Muslim. Masjid berperanan sebagai paksi kehidupan seorang Muslim iaitu kehidupan yang berteraskan keagamaan.

Pengkaji lepas Zulkiflee Haron, Mohd Nasir Ripin, Farahwahida Mohd Yusof (2008) menghuraikan masjid adalah Markaz al-Ummuh yang merupakan institusi terpenting dalam proses bina insan. Sejarah mencatatkan bahawa pembinaan masjid di Quba' oleh Baginda Rasulullah SAW bukan semata-mata bertujuan melaksanakan ibadat rutin sahaja tetapi juga sebagai titik permulaan menjana pendidikan umat manusia sehingga melahirkan kecemerlangan tamadun. Kepelbagaian rekabentuk masjid sejak zaman dahulu memaparkan kehebatan idea yang kreatif. Bentuk masjid yang dibina mengikut adat budaya masyarakat berpandukan ajaran Islam. la menarik minat masyarakat Islam dan bukan Islam dalam menghayati keindahannya dari luar dan dalam rumah ibadat umat Islam yang menakjubkan.

Bagi Wahad, Hamid, \& Norajila Che Man (2016), masjid merupakan tempat untuk menyuburkan jiwa insan agar sentiasa memperingati Allah S.W.T dalam apa jua keadaan sama ada ibadat umum mahupun khusus. Pembangunan insan yang berteraskan kepada keimanan dan ketaqwaan boleh membentuk masyarakat yang kuat sekaligus dapat menjalani kehidupan yang baik dan sejahtera. Pengukuhan iman dan jiwa menjadikan masyarakat taat dalam melakukan kebaikan dan menjauhi kemungkaran. Masjid juga berperanan sebagai pusat pembangunan insan yang berpaksikan kepada akidah yang sebenar dalam membina masyarakat ke arah memiliki nilai-nilai hidup yang mulia.

Fikiran manusia berfungsi secara simbolis apabila beberapa pengalaman, kesedaran, kepercayaan, perasaan dan gambaran melalui pengalaman yang lain. Simbol berasal dari Yunani iaitu symboion (memberi kesan). Simbol atau lambang menjadi saranan untuk membuat dan menyampaikan suatu pesan, menyusun sistem epistimologi dan keyakinan. Pengertian simbol sebagai suatu lambang digunakan sebagai penyampai pesan atau keyakinan dan memiliki makna tertentu. Makna khusus tersebut berupa unit khusus dalam konteks ritual. Simbol juga bermaksud unit terkecil dalam ritual khusus. Permasalahan yang mahu dirungkai dalam penulisan ini ialah tentang kekaburan jenis-jenis symbol yang terdapat dalam rekabentuk masjid warisan khususnya Masjid Muhammadi, Kota Bharu, Kelantan. Penjelasan yang terperinci mengenai simbol yang terdapat di Masjid Muhammadi tidak ditemui dalam mana-mana 
bahan rujukan. Dengan itu, penelitian awal yang dilakukan di Masjid Muhammadi ini adalah difokuskan kepada penerokaan terhadap simbol-simbol yang terdapat di masjid tersebut.

Penulisan ini akan dilanjutkan dengan penerangan tentang konsep simbol dan tanda diikuti dengan kaedah penyelidikan. Seterusnya hasil kajian dibentang dan dibincangkan diikuti dengan kesimpulan.

\subsection{Simbol Dan Tanda}

Laksmi Kusuma Wardani (2010) menghuraikan, simbol adalah pusat tertentu sebuah saranan komunikasi dan landasan pemahaman bersama. Setiap komunikasi dengan bahasa atau saranan yang lain menggunakan simbol-simbol. Simbol merupakan motif, corak dan ragam hias yang digunakan dalam rekabentuk masjid warisan. Elemen simbol menjadi sebahagian daripada elemen yang penting dalam rekabentuk untuk menghuraikan nilai estetik dalam masjid warisan. Namun begitu, pemilihan simbol ini dipengaruhi oleh pemikiran dan idea seni bina Islam. Dalam rekabentuk Masjid Muhammadi ini, ia mempunyai tiga jenis simbol. Antaranya ialah kaligrafi khat nasakh, geometri pecahan lapan dan motif greek-corinthian berdasarkan kepada pemerhatian kajian awal yang dijalankan.

Simbol yang dipilih untuk diterapkan dalam setiap rekabentuk masjid itu mempunyai pengaruh dan falsafah yang tersendiri (Nangkula Utaberta dan Mohamad Tajudin Mohamad Rasdi, 2013). Contohnya, Masjid Universiti Teknologi Malaysia dikatakan mempunyai elemen-elemen dengan mengambil inspirasi seni bina Gerbang Iwan di Iran, menara daripada Blue Mosque di Turki dan kubah daripada Masjid Shah di Isfahan (Kajian Lapangan \& Michell, George, 1995) (Nangkula Utaberta dan Mohamad Tajudin Mohamad Rasdi, 2013). Pembinaan masjid juga dipengaruhi oleh zaman contohnya Masjid Tengkera, Masjid Pengkalan Hulu dan Masjid Tanjung Keling di Melaka yang mempunyai unsur Cina-Pagoda disebabkan hubungan perdagangan yang kuat dengan China pada masa dahulu. Masjid-masjid lain contohnya Masjid Kampung Laut dan Masjid Mulong yang terdapat di Kelantan juga mempunyai pengaruh yang mengikut zaman. Tambahan pula, simbol itu dikaitkan dengan pengaruh zaman pembinaan masjid tersebut contohnya Masjid Muhammadi yang dibina pada zaman Inggeris pada tahun 1922 dan konsep pembinaan Masjid Muhammadi ini lebih kepada pengaruh Barat. Ini menunjukkan simbol dalam rekabentuk masjid dipengaruhi dan mempunyai falsafah dalam pembinaannya. Oleh itu, kajian awalan ini diteruskan untuk mengesahkan simbol seperti motif greek corinthian, kaligrafi dan geometri yang terdapat dalam rekabentuk Masjid Muhammadi

Anisah Ahmad (2015) menjelaskan terdapat beberapa motif dan simbol visual yang terdiri daripada unsur flora, fauna, geometri dan kosmos yang menjelaskan keunikan bangunan tersebut. Oleh itu, simbol memainkan peranan penting untuk melihat keindahan dalam setiap rekabentuk.

Penghasilan ukiran pada mimbar mempunyai jenis corak yang pelbagai dan dihasilkan dengan menggunakan kayu sebagai bahan utama. Penggunaan pelbagai jenis motif flora, geometri dan kosmos pada permukaan mimbar menghiasi masjid dengan kepelbagaian ukiran. Manakala, kesenian ukiran Islam juga mempunyai bentuk haiwan 
tetapi selagi tidak melanggar syariat Islam, ukiran tersebut boleh digunakan sebagai hiasan masjid.

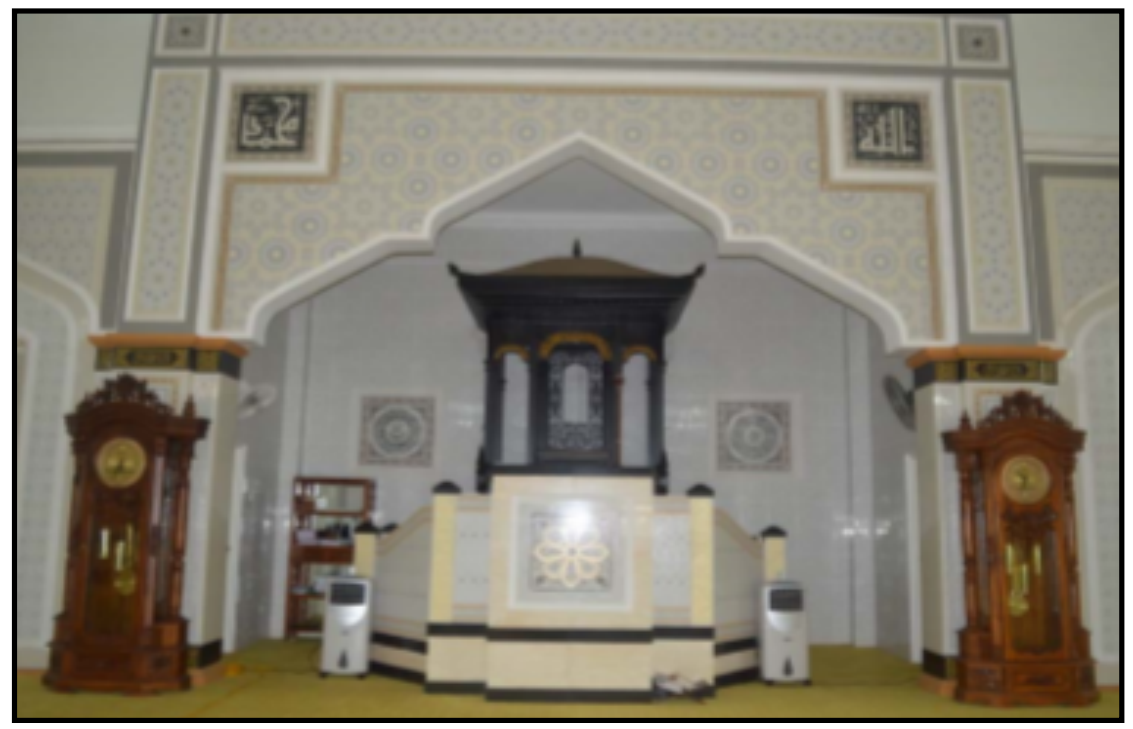

Rajah 6: Mimbar Masjid Terengganu

Sumber: Zuliskandar Ramli et. al (2014)

Kesenian simbol ini dapat dilihat dari segi pelbagai pengaruh seperti kesenian Islam, kesenian Cina dan kesenian ukiran. Menurut Syaimak Ismail et. al (2012), pembentukan kesenian simbol Cina diasaskan kepada fahaman animisme dan juga agama Buddha, namun hiasannya tidak melanggari syariat Islam. Tambahan pula, ruangan bangunan dapat ditonjolkan melalui pertukangan yang amat mengagumkan malah menunjukkan kemahiran tukang ukir terhadap simbol yang dimanifestasikan kepada bentuk nyata. Rekabentuk masjid ini juga boleh menerima pengaruh agama lain selagi tidak melanggar syariat Islam.

Motif Cina dapat dilihat melalui motif bunga, buah, haiwan, kosmos, geometri dan fenomena. Di Melaka, banyak masjid yang dipengaruhi oleh China. Antaranya ialah Masjid Kampung Keling, Masjid Kampung Hulu dan Masjid Tengkera yang agak ketara telah menerima pengaruh daripada China. Masjid ini dibina semasa pemerintahan Belanda sekitar tahun 1728M hingga 1748M. 


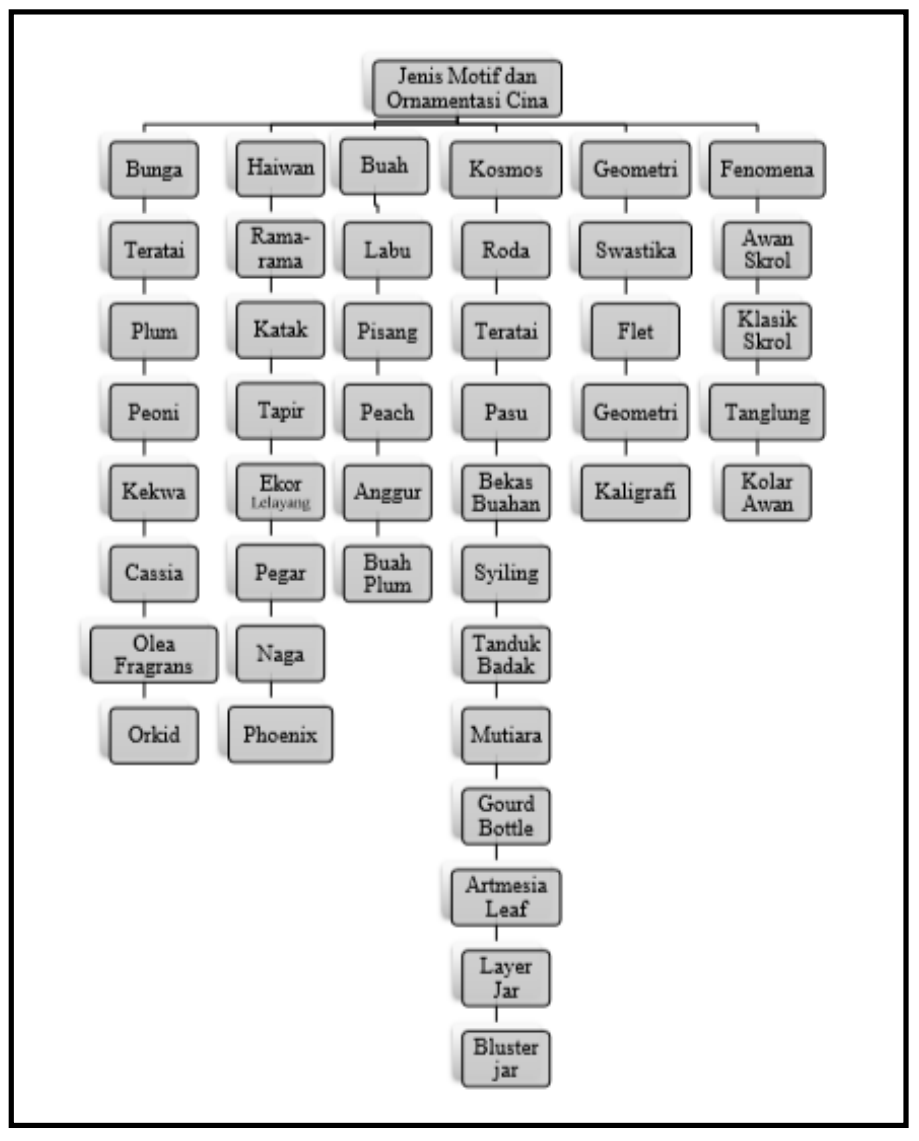

Rajah 7: Jenis Motif dan Ornamentasi di Seluruh Masjid di Melaka Sumber: S. Ismail, 2015

Menurut Ludin \& Ahmad Suhaimi Mohd. Nor (1995), dekoratif dan ornamentif adalah salah satu kelengkapan yang penting dalam seni bina Islam yang biasanya memberikan kesan khusus kepadanya. Biasanya, hiasan yang dipakai bagi mengisi ruang dalaman terdiri daripada seni ukir, stuco, fresco dan sebagainya. Unsur seperti bentuk, garisan, ruang rentak dan warna serta perpaduan antara pelbagai unsur dapat melahirkan suatu kesatuan yang kukuh. Antaranya ialah hiasan arabes, pola hiasan geometri dan ornamen khat-khat kufi hingga abad ke-7 Masihi. Tulisan yang dijalinkan dengan ukiran menjadikan motif hiasan hanyalah tulisan khat kufi dan tulisan lain yang berada di bawah jenisnya. Seni ukir Islam mempunyai nilai yang sangat tinggi seperti susunan, komposisi, pengisian ruang yang dihias mahupun kaedah atau teknik motif itu dilaksanakan.

Motif-motif semulajadi seperti daun, bunga, akar, dahan, ranting dan sebagainya digayakan menurut kehalusan rasa. Dalam seni Islam, terlihat perpaduan yang harmoni antara rasa dan fikiran. Motif pelbagai ukiran yang dilakukan di permukaan seperti kayu, batu, konkrit, bata, simen dan sebagainya termasuklah emas. Seni ukir yang biasanya dijalinkan dengan seni tulis merupakan satu keistimewaan dan sering menjadi hiasan bangunan-bangunan Islam. Ukiran itu tidak sekadar sebagai kewujudan seni untuk seni atau sebagai curahan rasa indah sahaja tetapi turut memberikan kesan lain yang lebih mendalam iaitu kesan keindahan yang mendekatkan perikemanusiaan dengan rasa ketuhanan yang tinggi. Kesenian simbol, 
motif cina dan motif-motif flora ini merupakan simbol yang terdapat dalam rekabentuk masjid Malaysia. Kepelbagaian simbol dalam rekabentuk memberi keunikan dalam sesuatu rekabentuk masjid tersebut. Simbol ini juga boleh memberi keunikan dan keindahan dalam rekabentuk masjid di Malaysia.

Menurut Nuralia (2018), salah satu elemen yang menarik untuk dikaji pada masjid kuno adalah ragam hias yang berupa kaligrafi tulisan arab (Islam) yang mempunyai makna tersirat sebagai hiasan iaitu terdiri daripada potongan ayat-ayat suci al-Quran dan hadis nabi serta tulisan ayat yang mempunyai makna. Pada masjid kuno Cikoneng Anyer Indonesia misalnya mempunyai ragam hias dan kaligrafi yang terpahat pada dinding di bahagian masjid. Kaligrafi adalah salah satu penelitian epigrafi iaitu salah satu bahagian daripada arkeologi yang mempunyai budaya lampau termasuklah epigrafi Islam. Kaligrafi Islam ini dijumpai pada dinding masjid zaman Belanda yang menunjukkan adanya warisan budaya Islam yang bercampur dengan budaya Barat. Kaligrafi Islam melambangkan perkataan, sikap dan perbuatan melalui bahasa. Kaligrafi Islam juga mempunyai sejarah tradisi cara penulisan yang indah dari Negara Arab sebagai tanah suci yang bermulanya tulisan kaligrafi dan disebut juga sebagai khat. Kaligrafi ini berasal daripada perkataan 'kaligraphia' yang bermaksud tulisan indah.

\subsection{Kaedah Penyelidikan}

Kaedah penyelidikan yang diguna dalam penulisan ini adalah menjurus kepada kaedah kualitatif secara kajian lapangan dan pemerhatian. Kajian lapangan ini yang dijalankan di Masjid Muhammadi dengan membuat pemerhatian ke atas simbol-simbol yang terdapat pada Masjid Muhammadi Kota Bharu dan memberi tafsiran berdasarkan teori semiotik.

\section{Teori Semiotik}

Menurut Mana Sikana (2016), teori semiotik diperkenalkan oleh C.S Pierce pada tahun 1839 hingga tahun 1914 dengan mengemukakan teori segitiga makna tanda, objek dan interpretasi. Tanda adalah sesuatu yang berbentuk fizik yang dapat diungkap oleh pancaindera manusia dan merupakan sesuatu yang merujuk kepada representasi hal lain di luar tanda itu sendiri. Menurut Pierce, tanda terdiri daripada simbol, ikon dan objek. Objek menunjukkan konteks sosial yang menjadi referensi dari tanda atau sesuatu yang dirujuk sebagai tanda. Interpretasi atau pengguna tanda adalah konsep pemikiran dari manusia yang menggunakan tanda dan memberi sesuatu makna tertentu dalam fikiran seseorang tentang objek yang dirujuk oleh sebuah tanda. Hal yang terpenting dalam proses semiosis adalah bagaimana makna muncul daripada sebuah tanda itu digunakan semasa berkomunikasi. Berikut merupakan rajah perkaitan teori semiotik yang dikeluarkan oleh C. S. Pierce: 


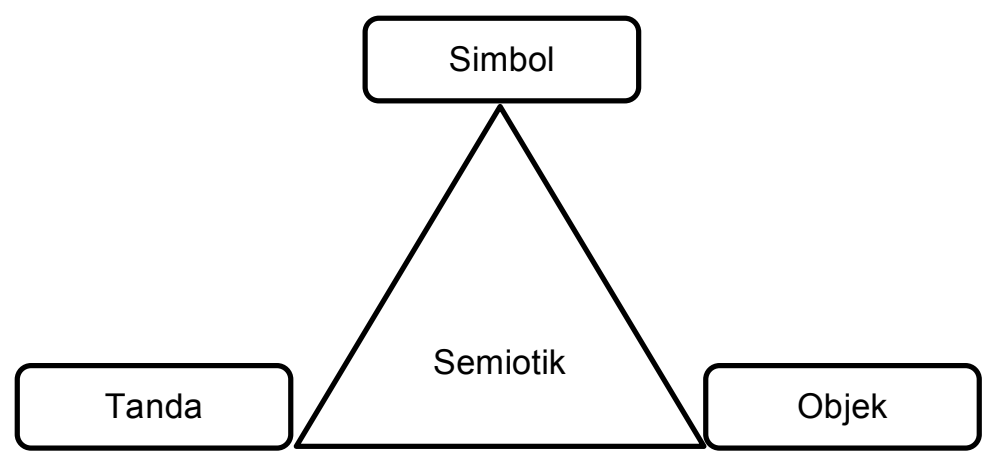

Rajah 8: Perkaitan Teori Semiotik C.S Pierce

Sumber: Mana Sikana (2016)

Semiotik Pierce didefinisikan sebagai teori umum untuk tanda yang meliputi satu bidang yang tua. Bidang lingkungan Pierce menjangkau kepada simbol-simbol gambar dan angka. Kajian ini menggunakan teori semiotik untuk melihat simbol yang digunakan dalam rekabentuk Masjid Muhammadi, Kota Bharu Kelantan. Penggunaan teori sangat penting dalam sesebuah kajian untuk memberi panduan kajian supaya kajian tidak tersasar ke arah lain. Teori semiotik yang dikeluarkan oleh C. S. Pierce ini lebih kepada segitiga (Rajah 8) yng menerangkan tanda, simbol dan objek. Teori semiotik digunakan untuk melihat simbol yang digunakan dalam rekabentuk Masjid Muhammadi. Teori ini digunakan untuk melihat bagaimana simbol seperti motif flora, geometri dan kaligrafi memberikan makna seperti rekabentuk yang dihasilkan. Teori ini amat sesuai digunakan dalam kajian ini dalam melihat simbol dan perlambangan. Jadual di bawah menerangkan perkaitan teori semiotik C. S. Pierce dengan kajian yang dijalankan.

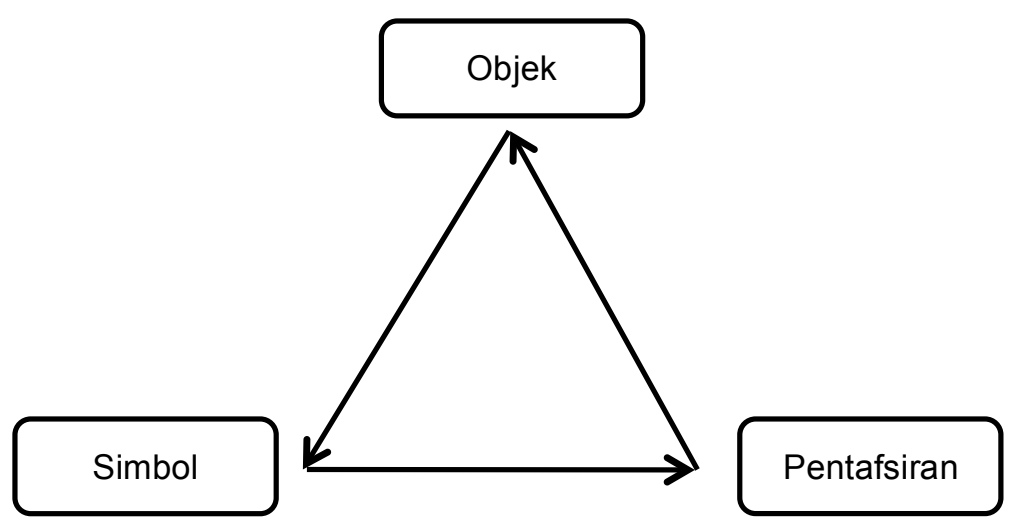

Rajah 9: Perkaitan Teori Semiotik C.S. Pierce dengan Kajian 


\subsection{Hasil kajian dan perbincangan}

\section{a. Latar Belakang Masjid Muhammadi, Kota Bharu, Kelantan}

Menurut Rosli Che Soh (2019), masjid Besar Kota Bharu mula didirikan pada tahun 1867. Masjid ini pada asalnya merupakan sebuah kayu yang terletak di pinggir Sungai Budor, Seberang Paloh, sebelum dipindahkan daripada tapak asal kerana ancaman banjir. Tidak terdapat sumber sahih yang menyatakan tarikh sebenar masjid ini mula dibina tetapi ianya dipercayai telah wujud sejak zaman pemerintahan Sultan Muhammad II yang memerintah Kelantan pada tahun 1837 hingga Oktober 1886. Ada juga pendapat yang menyatakan bahawa masjid ini telah dibina lebih awal lagi iaitu pada zaman pemerintahan Sultan Muhammad I antara tahun 1801 hingga 1837. Pada tahun 1921, sebuah bangunan baru (bangunan induk) mula dibina bagi menggantikan bangunan sedia ada daripada kayu.

Rosli Che Soh (2019) menyatakan Masjid Besar Kota Bharu didirikan dengan menggunakan kayu dari masjid asal di Kampung Sungai Bador Seberang Paloh yang dipindahkan bagi mengelak ancaman banjir, manakala Saad Syukri Muda (1971) menyatakan masjid lama dikatakan telah dibina pada zaman pemerintahan Sultan Muhammad I pada tahun 1800 hingga 1835M. Malangnya, masjid yang dibina telah runtuh akibat daripada 'air bah' (banjir) (Saad Syukri Muda, 1971). Nama asal bagi Masjid Muhammadi pada ketika itu adalah Masjid Besar Kota Bharu. la juga dikenali dengan nama 'Masjid Kayu' dan masjid ini dibina pada tahun 1867 bersamaan 1283H pada zaman pemerintahan Sultan Muhammad II pada tahun 1830 hingga 1886 yang terkenal dengan gelaran 'Sultan Mulut Merah'.

Sebelum Majlis Agama Islam Kelantan (MAIK) ditubuhkan, kuasa pentabiran ke atas masjid, perlantikan imam dan pewujudan mukim-mukim Jumaat secara tradisinya terletak di bawah yang KDYMM al-Sultan Kelantan. Kuasa ini kemudiannya diteruskan kepada Pejabat Mufti pada peringkat pelaksanaan dengan bantuan Tok Kweng (jawatan setaraf Pengawa sekarang dan guru-guru agama setempat). Undang-undang yang berkaitan dengan pentadbiran masjid diluluskan oleh State Council pada 22 Ogos 1916 kepada MAIK. Undang-undang tersebut diberi nama Undang-undang dan Peraturan bagi Masjid dan Surau (Undang-undang No.10 tahun 1916) yang telah dimansuhkan bagi surau-surau di Negeri Kelantan.

Pada zaman Haji Musa bin Haji Wan Abdul Samad iaitu Mufti Kelantan yang ketiga telah mencetuskan idea untuk mendirikan Masjid Muhammadi. Pendapat lain juga menyatakan bahawa selepas MAIK ditubuhkan, bangunan induk Masjid Muhammadi mula dibina (Nik Mohamed Nik Mohd Salleh, 1985). 


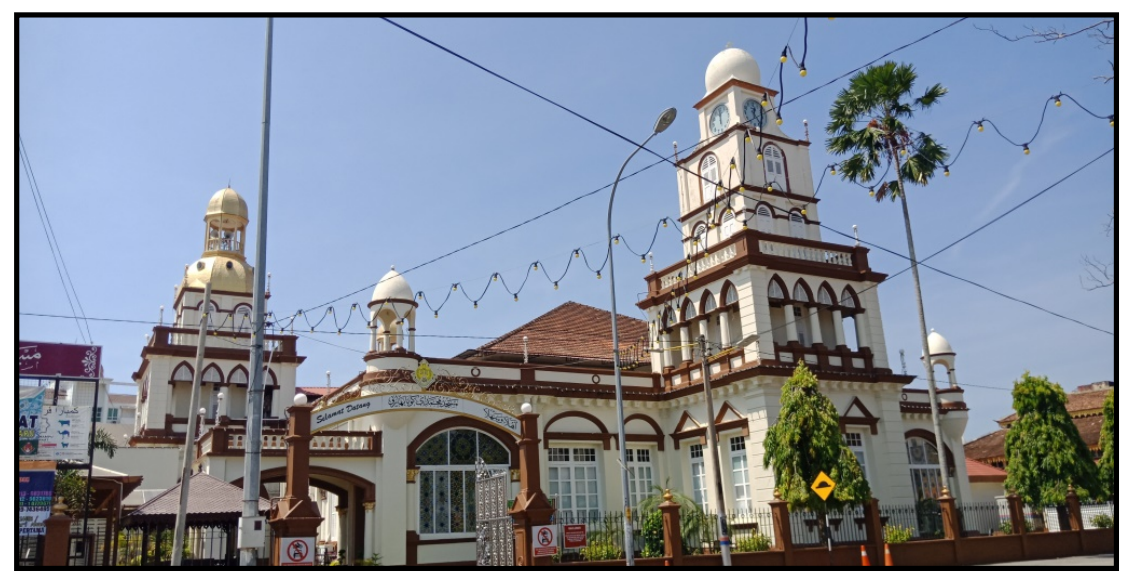

Rajah 1: Masjid Muhammadi Pandangan Sisi Depan

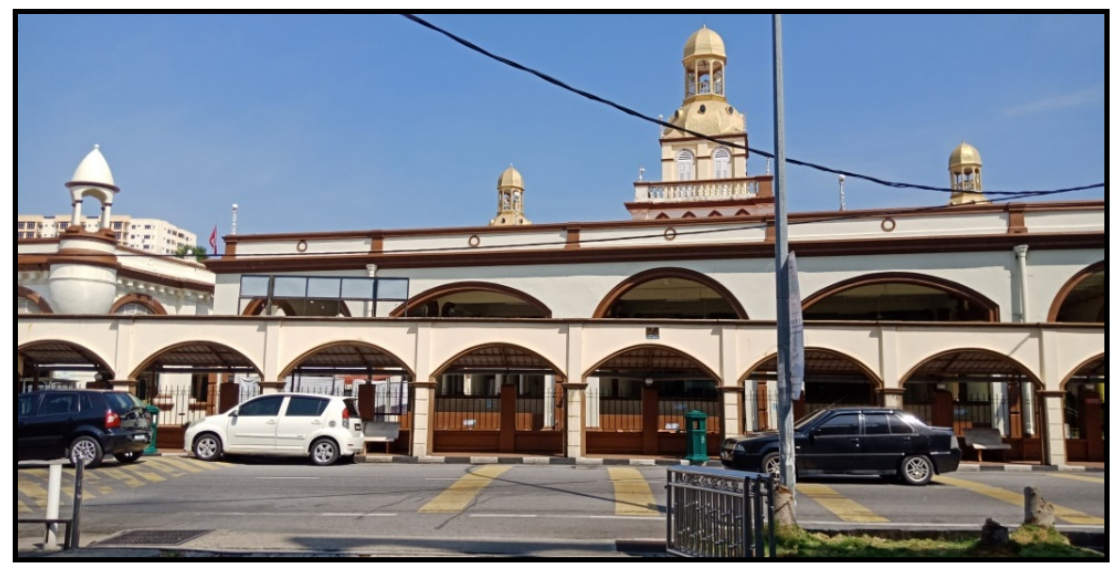

Rajah 2: Masjid Muhammadi Pandangan Sisi Belakang

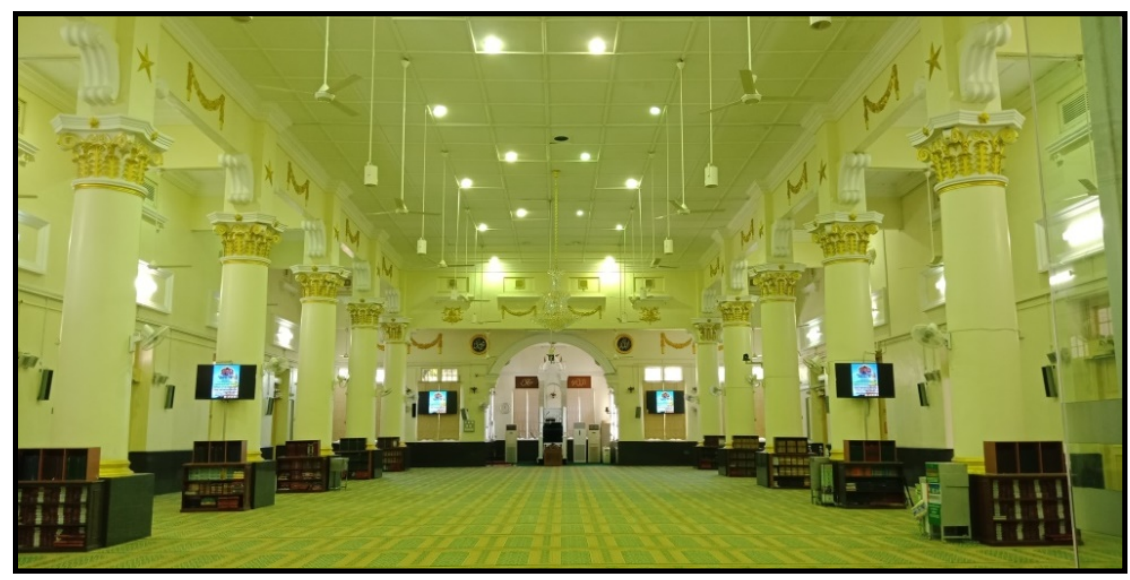

Rajah 3: Dewan Sembahyang Utama

Menurut Rosli Che Soh (2019), pembinaan batu asas seluas hampir 14000kaki persegi (132x106kaki persegi) dengan empat menara setinggi 21 meter telah menggantikan bangunan kayu selepas peletakan batu asas disempurnakan oleh KDYMM Baginda Almarhum Sultan Ismail Ibni Almarhum Sultan Muhammad IV pada 22 Ogos 1922. Pengubahsuaian bangunan masjid daripada kayu kepada struktur konkrit telah 
dilakukan oleh MAIK dan Adat Istiadat Melayu Kelantan melalui peruntukan daripada tabung zakat sebanyak RM360,000. Pembinaan Masjid Muhammadi ini pernah terbengkalai beberapa tahun di pertengahan dekad ke-20 kerana pihak MAlK kekurangan dana akibat kegawatan ekonomi yang melampau di seluruh dunia pada ketika itu. Pembinaan bangunan utama pada ketika itu dikatakan dapat menampung seramai 2400 jemaah. Masjid Muhammadi yang berstruktur konkrit telah dibuka secara rasmi pada 31 Julai 1931. Walaupun bangunan belum dirobohkan sepenuhnya, ianya telah dijadikan sebagai halaqah pengajian para ulamak pada masa itu. Keseluruhan bangunan kayu asal masjid dirobohkan sepenuhnya sekitar 1960-an dan kayu dihantar ke beberapa masjid di daerah lain untuk digunakan semula seperti Masjid Langgar yang menerima kayu daripada Masjid Muhammadi.

Luas keseluruhan masjid kini adalah 10,600 kaki persegi dan boleh menampung seramai 5000 orang ahli jemaah. Kos pengubahsuaian Masjid Muhammadi adalah sebanyak RM897,242. Antara peninggalan lama yang masih ada di Masjid Muhammadi adalah telaga besar Masjid Muhammadi yang dikenali juga sebagai Perigi Tok Kenali dan beduk besar yang dipalu sebelum azan berkumandang.

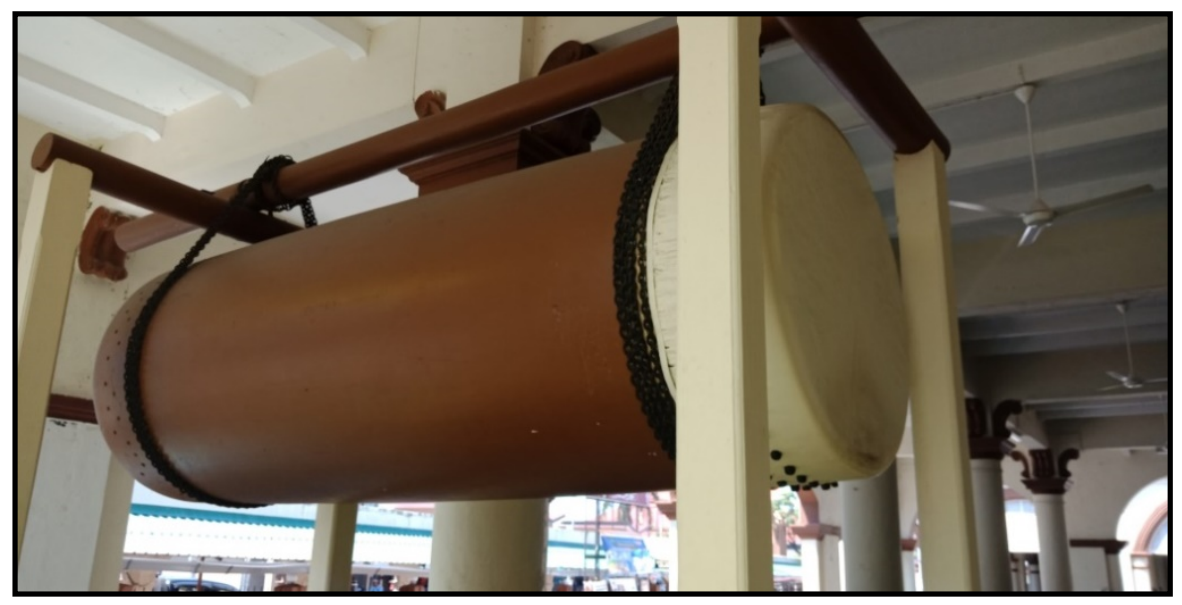

Rajah 4: Beduk Besar

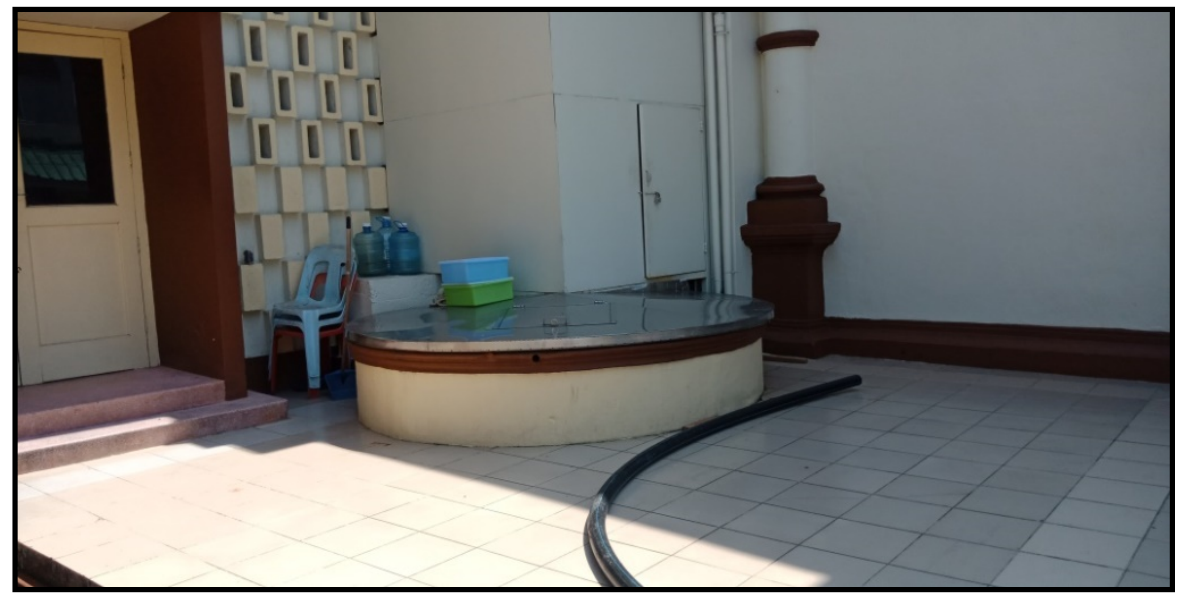

Rajah 5: Perigi Tok Kenali 


\section{b. Rekabentuk simbol pada Masjid Muhammadi, Kota Bharu, Kelantan}

Masjid Muhammadi mengalami kerja-kerja pengubahsuaian sebanyak empat kali iaitu pada tahun 1959, 1968, 1976 dan 1987 (Portal Rasmi Jabatan Kemajuan Islam Malaysia (JAKIM), 2017). Selepas pengubahsuaian dijalankan, dokumentasi bagi simbol atau motif yang terdapat di Masjid Muhammadi kurang teratur dan tidak sistematik. Semasa kajian awalan dijalankan, pengkaji mendapati beberapa simbol yang terdapat pada struktur Masjid Muhammadi adalah seperti motif flora, kaligrafi dan juga geometri. Penggunaan ragam hias ini telah menunjukkan identiti rekabentuk dalam pembinaan Masjid Muhammadi di Kota Bharu, Kelantan.

Hasil pemerhatian menerusi kajian lapangan mendapati rekabentuk Masjid Muhammadi yang dipengaruhi oleh beberapa ragam hias hasil daripada pengaruh kolonial. Misalnya, motif greek-corinthian yang terdapat pada tiang Masjid Muhammadi menunjukkan rekabentuknya dipengaruhi oleh kolonial iaitu pengaruh Rom. Ragam hias merupakan salah satu elemen dalam simbol yang ditonjolkan dalam rekabentuk bangunan. Ragam hias yang ditunjukkan dalam rekabentuk Masjid Muhammadi melambangkan nilai keindahan dan keunikan yang bercampur dengan pengaruh kolonial dalam rekabentuk bangunannya.

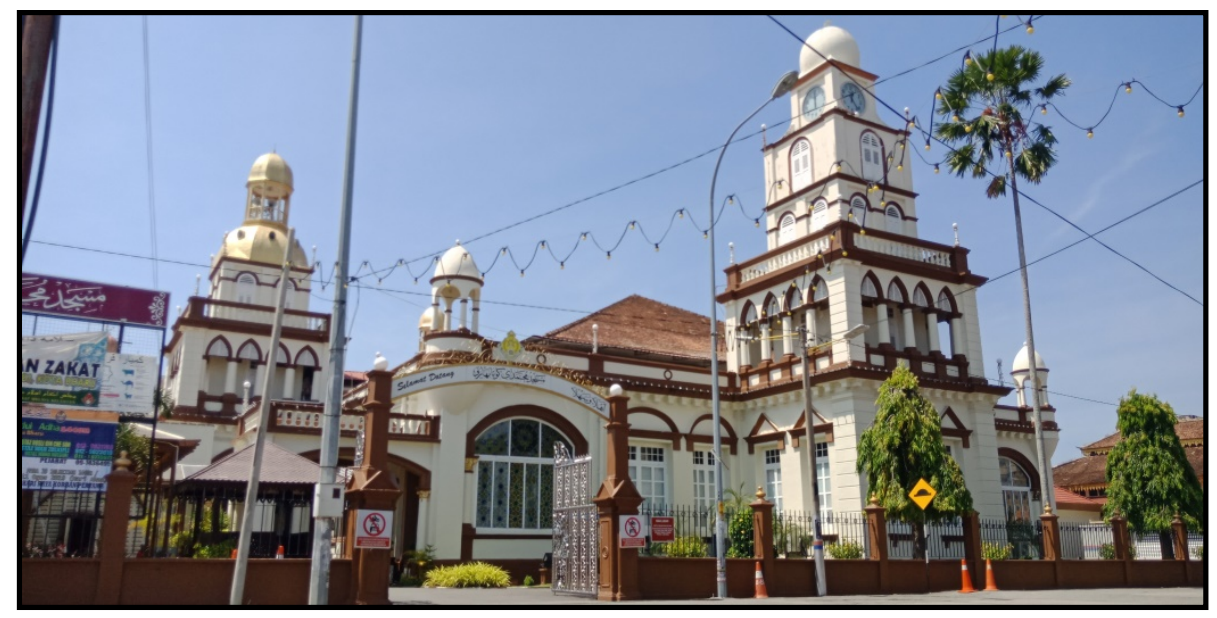

Rajah 10: Pengaruh kolonial pada rekabentuk Masjid Muhammadi, Kelantan

Menurut Rosli Che Soh (2019), sebelum Masjid Muhammadi dibina, satu rombongan termasuklah kontraktor telah melawat Masjid Sultan Abu Bakar di Johor Bharu untuk melihat rekabentuknya yang dipengaruhi oleh pengaruh kolonial. Rekabentuk kolonial juga dapat dilihat dalam nilai keindahan dan keunikan apabila rekabentuknya digabungkan dengan pengaruh Islam. 


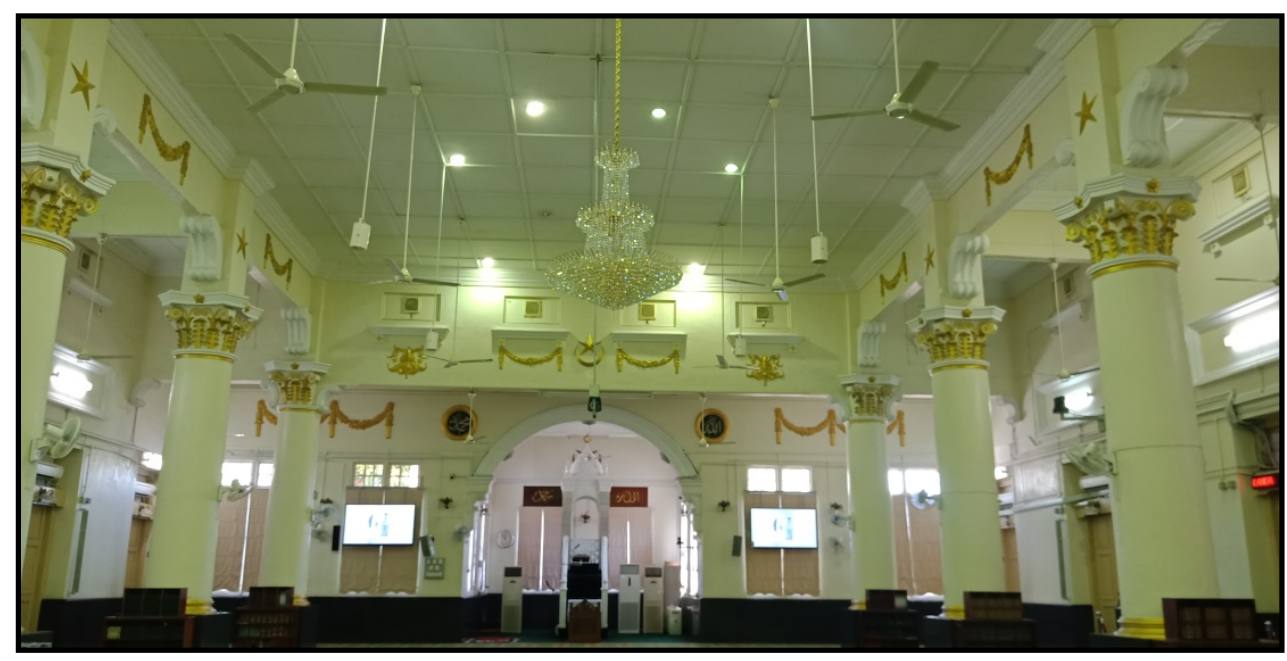

Rajah 11: Gabungan rekabentuk Islam dan kolonial Masjid Muhammadi

Penggabungan ragam hias pengaruh Rom dan pengaruh Islam ini menunjukkan nilai keindahan dan keunikan dalam ekabentuk bangunan Masjid Muhammadi Kota Bharu, Kelantan. Kesesuaian ragam hias dalam rekabentuk Masjid Muhammadi juga merupakan salah satu nilai keindahan alam rekabentuknya. Hal ini kerana ragam hias yang dipilih dalam rekabentuk mestilah bersesuaian dengan konsep rekabentuk. Sekiranya ragam hias ini dipilih dan bercanggah dengan konsep asal rekabentuknya, nilai keindahan yang ditonjolkan akan kelihatan kurang menarik. Faktor pemilihan ragam hias juga memainkan peranan penting untuk menunjukkan nilai keindahan dalam rekabentuk Masjid Muhammadi Kota Bharu, Kelantan.

Kajian ini menggunakan teori semiotik yang diasaskan oleh C. S. Pierce untuk melihat tanda dan simbol dalam Masjid Muhammadi. Proses pemerhatian yang dijalankan kajian lapangan mendapati tanda yang digunakan dalam rekabentuk Masjid Muhammadi adalah simbol motif greek-corinthian, kaligrafi nasakh dan geometri.

Oleh itu, pemilihan ragam hias merupakan salah satu faktor penting untuk melihat nilai keindahan dalam rekabentuk Masjid Muhammadi. Nilai keindahan dan keunikan yang ditonjolkan dalam rekabentuk Masjid Muhammadi jelas dilihat dalam ragam hias yang dipilih yang bersesuaian dengan rekebentuk asalnya.

\subsection{Kesimpulan}

Perkaitan simbol dalam sesebuah rekabentuk sangat berkait rapat dan mempunyai makna yang tersendiri. Tambahan pula, pemilihan simbol dalam rekabentuk yang bersesuaian menambahkan lagi keunikan dan keindahan pada bangunan tersebut. Oleh itu, simbol dalam rekabentuk ini saling berkait antara satu sama lain. Jelaslah bahawa Masjid Muhammadi juga mempunyai simbol tertentu dalam rekabentuknya.

Penggunaan teori semiotik dalam kajian awalan ini juga dapat membantu untuk melihat keunikan simbol dalam rekabentuk Masjid Muhammadi di Kota Bharu. Struktur rekabentuk Masjid Muhammadi dipengaruhi oleh rekabentuk Barat terutama di bahagian tiang, kubah, menara dan dewan sembahyang utama Masjid Muhammadi. Penggunaan teori estetika turut digunakan dalam kajian awalan ini bagi menghurai 
secara terperinci mengenai keunikan dan keistimewaan simbol dalam struktur rekabentuk Masjid Muhammadi.

Secara tuntasnya, simbol merupakan salah satu komponen yang penting untuk melihat nilai keindahan dan keunikan dalam bangunan warisan. Oleh itu, pemilihan simbol ini sangat penting dalam setiap rekabentuk masjid warisan bagi melihat keindahan dan keunikan masjid tersebut. Apabila keunikan dan keindahan bangunan itu menjadi terserlah, ini boleh menarik minat masyarakat untuk melawat bangunan-bangunan bersejarah dan seterusnya mampu menaikkan imej bangunan warisan yang ada di Malaysia.

\section{Rujukan}

Anisah Bahyah Ahmad. (2015). Motif Dekorasi Dalaman Masjid : Kajian Terhadap Masjid Kampung Keling di Melaka. Faculty of Islamic Studies, UKM, Selangor, Malaysia.

Asmak Haji Ali, Cik Hashim Mat Said. (2008). Peranan Masjid dalam Masyarakat Hadhari dalam buku Fungsi dan Peranan Masjid dalam Masyarakat Hadhari ditulis oleh Mohd Ismail Mustari Karjo, Kamarul Azmi Jasmi. Universiti Malaysia Kelantan.

Ismail, S., Yusof, A., \& Ahmad Zaki Berahim@Ibrahim. (2013). Motif dan Hiasan Cina Dalam Dekorasi Dalaman Masjid: Kajian terhadap Masjid Tua Di Melaka pada wal Abad ke 18. In Motif dan Hiasan Cina Dalam Dekorasi Dalaman Masjid: Kajian Terhadap Masjid Tua di Melaka Abad ke-18 (p. 15).

Laksmi Kusuma Wardani. (2010). Fungsi, Makna dan Simbol (Sebuah Kajian Semiotik). Seminar Jelajah Arsitektur Nusantara!01010, 10. Institut Teknologi Sepul Nopember.

Ludin, M. M., \& Ahmad Suhaimi Hj. Mohd. Nor. (1995). Aspek-Aspek Kesenian Islam (Cetakan $\mathrm{Pe})$. https://doi.org/Percetakan Dewan Bahasa dan Pustaka

Mana Sikana. (2016) Penilaian dan Wacana Dinamika dalam Sastera Melayu. pemacudbp.dbp.gov.my. Dewan Bahasa Pustaka

Mohd Ismail, M., \& Kamarul Azmi, J. (2008). Fungsi dan Peranan Masjid Masyarakat Hadhari. Retrieved from www.penerbit.utm.my

Nangkula Utaberta dan Mohamad Tajudin Mohamad Rasdi. (2013). Pemikiran Seni Bina Islam Moden Di Dunia dan Malaysia. Cetak Ratu Sdn.Bhd.

Nuralia, L. (2018). Kaligrafi Islam Pada Dinding Masjid Kuna Cikoneng Anyer-Banten: Kajian Arti Dan Fungsi. Berkala Arkeologi, 37(1), 85. https://doi.org/10.30883/jba.v37i1.82

Portal Rasmi Jabatan Kemajuan Islam Malaysia (JAKIM). (2017). http://masjid.islam.gov.my/index.php?data=aW5mby1tYXNqaWQucGhw\&id=13\&jenis=\&n ama $=\&$ negeri $=\&$ daerah $=$

Rosli Che Soh. (2019). Sejarah Penubuhan Masjid Muhammadi. Pejabat Masjid Muhammadi. 
S. Ismail. (2003). Definisi Teori Estetika. Universiti Malaya. studentsropo.um.edu.my

S. Ismail. (2015). Motif Dan Ornamentasi Cina Pada Komponen Masjid Di Melaka. studentsrepo.um.edu.my

Syaimak Ismail, Abdullah Yusof, Ahmad Zaki Berahim@Ibrahim. (2013). Motif dan Hiasan Cina dalam Dekorasi Dalaman Masjid : Kajian terhadap Masjid Tua Di Melaka pada Awal Abad ke-18. http://umexpert.um.edu.my/life/publication/00002707_91920.pdf

Wahad, N. A. A., Hamid, N. A., \& Norajila Che Man. (2016). Pemerkasaan Peranan Masjid Di Malaysia Era Kontemporari. E-Academic Journal UiMtT, Volume 5(Issue2), 11.

Zulkiflee Haron, Mohd Nasir Ripin, Farahwahidam Mohd Yusof. (2008). Masjid sebagai Institusi Pendidikan : Sorotan Abad ke 3H - 5H. Dalam buku Fungsi dan Peranan Masjid dalam Masyarakat Hadhari. (2008). Penulis Mohd Ismail Mustari Karjo, Kamarul Azmi Jarmi. Universiti Teknologi Malaysia.

Zuliskandar Ramli, Noor Hafiza Ismail, Hamdun Haron, Salina Abdul Manan, Azni Hanim Hamzah. (2014). Prosiding Seminar Antarabangsa ke-3 Arkeologi, Sejarah dan Buaya di Alam Melayu. Universiti Kebangsaan Malaysia, Bangi, Selangor. 